\title{
ANALYSIS OF THE JUDGMENT ISSUED \\ BY THE COURT OF JUSTICE OF THE EUROPEAN \\ UNION (CJEU) IN CASE C I6I/I7 (CORDOBA CASE)
}

GABRIEL ERNESTO MELIAN PÉREZ*

\section{ABSTRACT}

This note discusses the most important elements of the decision of the Court of Justice of the European Union (CJEU) in the Cordoba case. The Court ruled that the unauthorized republication of photographs constitutes an act of communication to the public and therefore a copyright infringement. This ruling clarified the scope of the right of "communication to the public" in the framework of the Infosoc Directive and the legality of republishing copyrighted material on the Internet. Its most important contribution is to establish the differences between the use of links and framing with respect to re-posting cases. This commentary analyses whether it is still appropriate to continue using the criteria of "new public" to identify infringements of the right of "communication to the public".

Keywords: Copyright; Communication to the public; Hyperlinks; New Public; Exhaustion of the right.

ANÁLISIS DE LA SENTENCIA PROFERIDA POR EL TRIBUNAL DE JUSTICIA

DE LA UNión EUROPEA (TJUe) EN EL ASUNTO C I6I/I7 (CASO CóRdOba)

\section{RESUMEN}

Esta reseña aborda los elementos más importantes de la decisión del Tribunal de Justicia de la Unión Europea (TJUE) en el caso Córdoba. El Tribunal determinó que

* LL.M. in Intellectual Property and Information Technology Law (University of Göttingen). Former Specialist in Inventions and Trademarks at the Cuban Industrial Property Office. Halle (Saale) (Alemania). Contacto: gmelianperez@gmail.com. Fecha de recepción: $1 .^{\circ}$ de marzo de 2021. Fecha de aceptación: 17 de marzo de 2021. Para citar el artículo: Melian Pérez, Gabriel Ernesto. "Analysis of the judgment issued by the Court of Justice of the European Union (CJEU) in case C 161/17 (Cordoba case)" en Revista de la propiedad inmaterial n. ${ }^{\circ}$ 31, Universidad Externado de Colombia, enero-julio 2021, pp. 271-281. DoI: https://doi.org/10.18601/16571959.n31.10 
el re-posteo no autorizado de fotografías constituye un acto de comunicación al público y, por tanto, una infracción de los derechos de autor. Esta sentencia aclara el alcance del derecho de "comunicación al público" en el marco de la Directiva Infosoc y la legalidad del re-posteo de material que se encuentra protegido por derechos de autor en Internet. Su aportación más importante radica en establecer las diferencias entre el uso de links y framing con respecto a los casos de re-posting. En este comentario se analizará si sigue siendo adecuado continuar utilizando el criterio de "nuevo público" para identificar infracciones del derecho de "comunicación al público”.

Palabras clave: Derecho de autor; comunicación pública; hipervínculos; nuevo público; agotamiento del derecho.

In this discussion we will attempt to address the decision (Advisory Opinion/Preliminary Ruling) in what is known as the "Cordoba case", also called the "Renckhoff case" 1 . The request for interpretation arises from the German jurisdiction ${ }^{2}$, which asks the Court of Justice of the European Union (CJEU) to interpret the meaning of "communication to the public" within the framework of the EU Directive $2001 / 29 / \mathrm{EC}^{3}$. The request for interpretation in this case concerns unauthorized re-posting of photographs on websites.

\section{FACTS OF THE CASE DIRK RENCKHOFF V. LAND NORDRHEIN-WESTFALEN}

Since March 25, 2009, the Gesamtschule Waltrop (Waltrop Secondary School) made available on its website a school assignment by one of its pupils which contained, for illustrative purposes, a photograph of Cordoba city taken by $\mathrm{Mr}$. Renckhoff (professional photographer). The student had downloaded the image from a travel website as it was available without any restrictive measures to prevent it. Below the photograph, the student had included a reference to that website.

Mr. Renckoff understood that he had granted a right of exclusive use to the travel portal only. Therefore, he considered the unauthorized use of the photograph

1 C 161/17, Judgment of the Court (Second Chamber), 7 August 2018, ECLI:EU:C:2018:634.

2 This prerogative is recognized in Article 267 of the Treaty on the Functioning of the European Union: "The Court of Justice of the European Union shall have jurisdiction to give preliminary rulings concerning: (a) the interpretation of the Treaties; (b) the validity and interpretation of acts of the institutions, bodies, offices or agencies of the Union; Where such a question is raised before any court or tribunal of a Member State, that court or tribunal may, if it considers that a decision on the question is necessary to enable it to give judgment, request the Court to give a ruling thereon."

3 Directive 2001/29/EC of the European Parliament and of the Council of 22 May 2001 on the harmonisation of certain aspects of copyright and related rights in the information society. Official Journal L 16, 22/06/2001 P. 0010-0019. Also known as the Infosoc Directive, it is a European Union directive that was enacted to harmonize certain aspects of copyright across Europe. 
on the school's website, constituted an copyright infringement ${ }^{4}$. Based on this argument, Mr. Renckhoff, initiated legal proceedings against the City of Waltrop ${ }^{5}$ and Land of North-Rhineland-Westphalia ${ }^{6}$, before the Landgericht Hamburg (Regional Civil and Criminal Court of Hamburg, Germany).

\section{PROCEDURAL STEPS}

As a first move, Mr. Renckhoff brought his lawsuit before the Hamburg Regional Court, alleging copyright infringement. He asked the first instance court to prohibit the Land of North Rhine-Westphalia from reproducing and making available to the public, itself or through third parties, his photograph and, subsidiarily, to prohibit it from allowing students to reproduce the photograph to post it on the Internet. He also claimed the payment of a sum of $€ 400$ EUR in compensation for damages. Mr. Renckhoff's claim was partially upheld and the Land of North Rhine-Westphalia was ordered to remove the photograph from the school's website and to pay the sum of $€ 300$ EUR plus interest.

Both parties appealed against that judgment to the Oberlandesgericht Hamburg (Higher Regional Court for Civil and Criminal Matters in Hamburg, Germany), which held that the photograph was protected by copyright and its publication on the school's website had infringed Mr. Renckhoff's rights of reproduction and making available to the public. The court considered irrelevant the fact that the photograph could be accessed without restriction by anyone on the Internet, since the reproduction of the photograph on the server and the subsequent making available to the public on the school's website constituted a "disconnection" from the initial publication on the travel website. Therefore, the plaintiff - unlike when setting an electronic reference ("link") ${ }^{7}$ - no longer had sole control over his work.

Still not pleased with the decision, the Land of North-Rhineland-Westphalia appealed in cassation before the Bundesgerichtshof (Supreme Court for Civil and Criminal Matters, Germany). However, the Supreme Court considered that the outcome of the case depended on the interpretation of Article 3(1) ${ }^{8}$ of Directive $2001 / 29$.

4 The Urheberrechtsgesetz - UrhG (Act on Copyright and Related Rights) recognizes the Right of reproduction in its Section 16 and the Right of making works available to public in section $19 \mathrm{a}$.

5 The City of Waltrop is responsible for the Gesamtschule Waltrop. It was a defendant in the first instance but it was no longer a party on further proceedings.

6 The Land of North Rhine-Westphalia was also a defendant in this first instance, since they are in charge of the inspection of the school and the employer of the school's teachers.

7 The "link" allows the author to maintain some control over his work, since if he removes his work from the main source, the link would be useless. However, when a work is copied to another server, as the German court rightly points out, control over this work is lost. If the author decides to remove it from the primary site, the work will still be available to the public due to the copy that was made on another server.

8 "Article 3 of Directive 2001/29, entitled 'Right of communication to the public of works and right of making available to the public other subject matter' provides in paragraph 1: 1. Member States shall provide authors with the exclusive right to authorise 
In those circumstances, the Bundesgerichtshof (Federal Court of Justice, Germany) decided to stay proceedings and refer the following question to the Court for a preliminary ruling:

Does the inclusion of a work - which is freely accessible to all internet users on a thirdparty website with the consent of the copyright holder- on a person's own publicly accessible website constitute a making available of that work to the public within the meaning of Article 3(1) of [Directive 2001/29] if the work is first copied onto a server and is uploaded from there to that person's own website?

\section{I. DECISION (RULING) MADE BY THE CJEU}

The concept of "communication to the public", within the meaning of Article 3(1) of Directive 2001/29/EC [...] must be interpreted as meaning that it covers the posting on one website of a photograph previously posted, without any restriction preventing it from being downloaded and with the consent of the copyright holder, on another website.

Let us discuss the arguments used by the cJEU to reach this conclusion.

\section{ANALYSIS OF THE JUDGMENT}

After reading the opinion of the Advocate General and the final decision in the Cordoba case, one may feel a mixture of sensations, something like a bittersweet taste. Although in the end, I believe, that the court reached the correct decision differentiating the hyperlinks from the act of copying and posting a work; some of the arguments used were perhaps not entirely accurate. They introduced the controversial concept of the "new public" while not devoting more space to analyze the possible application of some exceptions such as Article 5(3)(a) of Directive 2001/29/CE?.

In the "Renckhoff" or "Cordoba" case, it was not the first time that the CJEU made a judgment on the concept of "communication to the public". Since Directive 2001/29/EC is not clear on this respect, the Cordoba case is preceded by several judgments that map out what is understood in case law as "communication to the public". Examples include: Società Consortile Fonografici (SCF) v Marco Del

or prohibit any communication to the public of their works, by wire or wireless means, including the making available to the public of their works in such a way that members of the public may access them from a place and at a time individually chosen by them. 3. The rights referred to in paragraphs 1 and 2 shall not be exhausted by any act of communication to the public or making available to the public as set out in this Article"”.

9 "Article 5. Exceptions and limitations: [... 3. Member States may provide for exceptions or limitations to the rights provided for in Articles 2 and 3 in the following cases: (a) use for the sole purpose of illustration for teaching or scientific research, as long as the source, including the author's name, is indicated, unless this turns out to be impossible and to the extent justified by the non-commercial purpose to be achieved...”. 
Corso $^{10}$; SGAE $v$ Rafael Hoteles ${ }^{11}$ and Football Association Premier League and Others $^{12}$. However, cases like Stichting Brein ${ }^{13}$, AKM ${ }^{14}$, GS Media ${ }^{15}$ and Svensson ${ }^{16}$ were fundamental to define the features and requirements that European jurisprudence grants to this right.

The elements of the case can be summarized as follows. A pupil in Germany downloaded a photograph of the city of Cordoba from a travel website and used it for a written school assignment. The assignment was then uploaded to the school's website. In other words, the work was first copied to a server and from there it was uploaded to the school's website. Let's see if this constitutes copyright infringement under European law, according to the reasoning of the CJEU.

\section{I. THE EXISTENCE OF A PROTECTED WORK (POSSIBLE LACK OF ORIGINALITY)}

It is usual that when a case involves a photograph and even more so when it is a "common" landscape, that the defendant will -at some point- try to challenge the copyright protection of that photograph on the grounds that it does not constitute a work. This is why the CJEU -based on the Painer case ${ }^{17}$ - refers to the standards set out in the Infopaq ${ }^{18}$ judgment. According to the aforementioned precedents -primarily the Infopaq case- it must be said that the requirements for copyright protection in Europe are relatively low. The only condition is for the work to be an "author's intellectual creation that reflects his personality and is result of his free and creative decisions". As stated by the CJEU, determining whether it constitutes a work or not, will always be the responsibility of the national court (para. 14). In this respect, the court acted correctly.

\subsection{COMmUNication to THE PUblic}

First, the court seems to be correct when it states in paragraph 16 of the judgment that any use of a work by a third party without the prior consent of the author,

10 C-135/10, Judgment of the Court (Third Chamber), 15 March 2012, ECLI:EU:C:2012:140.

11 C-306/05, Judgment of the Court (Third Chamber), 7 December 2006, ECLI:EU:C:2006:764.

12 C-403/08, Judgment of the Court (Grand Chamber), 4 October 2011, ECLI:EU:C:2011:631.

13 C610/15, Judgment of the Court (Second Chamber), 14 June 2017, ECLI: EU: C: $2017: 456$.

14 C138/16, Judgment of the Court (Eighth Chamber), 16 March 2017, ECLI:EU:C:2017:218.

15 C160/15, Judgment of the Court (Second Chamber), 8 September 2016, ECLI:EU:C:2016:644.

16 C466/12, Judgment of the Court (Fourth Chamber), 13 February 2014, ECLI:EU:C:2014:76.

17 C-145/10, Judgment of the Court (Third Chamber), 1 December 2011, ECLI:EU:C:2011:798.

18 C5/08, Judgment of the Court (Fourth Chamber), 16 July 2009, ECLI:Eu:C:2009:465. 
infringes copyrights (without prejudice to the application of the exceptions and limitations established in Law). It is a common misconception that just because a work is on the Internet without visible security measures, it means that it can be freely reproduced, communicated, or distributed. It is different to enjoy the work as a simple user than to copy that work and make it available to the public. The latter act directly infringes the author's economic rights, specifically the rights of reproduction and communication to the public.

Although the act of reproduction carried out by the student is clear and constitutes, in principle at least, a violation of copyrights, there is no unanimity regarding the infringement of the right of communication to the public by publishing the document on the school's website. The concept of "communication to the public" has been widely discussed by doctrine and in the European jurisprudence, since its meaning and extent were not defined by Directive 2001/29/EC, so it has been the task of the CJEU to develop it. Under the criteria established by the CJEU (in Stichting Brein), according to the text of Article 3.1 of Directive 2001/29/EC, communication to the public has two cumulative criteria: there must be an "act of communication"; and the communication of that work must be "to the public". This has been the criteria established by European case law and I personally agree with this reasoning.

Regarding the first element, namely the existence of an "act of communication", for such an act to exist it is sufficient "that a work is made available to a public in such a way that the persons forming that public may access it, irrespective of whether or not they avail themselves of that opportunity" (para. 20). In my opinion, by uploading a file on the school's website including a copy of Mr. Renckhoff's photograph, an "act of communication" of that work is obviously being carried out. "Such a posting gives visitors to the website on which it is posted the opportunity to access the photograph" (para. 21).

Regarding the second requirement, namely communication "to the public", it is clear from the Court's case-law ${ }^{19}$ that the concept of "public" refers to an indeterminate number of potential recipients. Those would be the total amount of people who have access to the school's website. Bearing in mind that this website is completely open and freely accessible, we must understand "public" as any user of the network. Therefore, the second requirement for communication to the public has been fulfilled (para. 23). So far, following the strict requirements established by Article 3.1 of Directive 2001/29/EC, we can affirm that in the Cordoba case exists a "communication to the public" and no further requirements should be imposed.

However, the court recognizes a number of extra requirements which on paragraph 24 which, although widely used in the jurisprudence of this court, are not in my opinion covered by Directive 2001/29/EC and have only made the problem worse rather than solving it. According to the Court's reiterated case law, 
in order to be qualified as "communication to the public", the communication of a protected work must, in addition to the two analyzed requirements, "be made using a technique different from those previously used", or to a "new public". That is, a public that was not taken into account by the copyright owner when he authorized the original communication of the work. In the Cordoba case, the discussion does not come from the use of a different technique, but from the issue of whether the photograph was presented to a "new public".

There were two conflicting approaches on this regard ${ }^{20}$. On one hand, the Land of North Rhine-Westphalia and the Italian Government claim, on the basis of the Svensson decision, that "there is no need to draw a distinction between the communication of a work by posting it on a website and the communication of such a work by including a hyperlink on a website which leads to another website on which that work was originally communicated without any restriction and with the consent of the copyright holder. Thus, in circumstances such as those at issue in the main proceedings, the work has not been communicated to a new public" (para. 27). On the other hand, Mr. Renckhoff, the French Government, and the Commission, argue that the Svensson case law is not relevant because this is not the same situation. In the Cordoba case, the communication is not made by means of a hyperlink, but the work itself is placed on a website, different from the one where it was already made available with authorization of the copyright holder. This constitutes a "new communication to the public". I personally consider that the latter is the correct approach.

But whenever the Svensson judgment is used as a basis, there will be criticism. For many specialists, this judgment is based on a mistaken argument, because it considers that hyperlinks are not even an act of communication ${ }^{21}$. Without entering

20 "The parties to the main proceedings and the interested parties referred to in Article 23 of the Statute of the Court of Justice of the European Union who have submitted written observations disagree..." [para. 26]. The aforementioned article 23 of the statute states the following: “... the decision of the court or tribunal of a Member State which suspends its proceedings and refers a case to the Court of Justice shall be notified to the Court by the court or tribunal concerned. The decision shall then be notified by the Registrar of the Court to the parties, to the Member States and to the Commission, and to the institution, body, office or agency of the Union which adopted the act the validity or interpretation of which is in dispute. Within two months of this notification, the parties, the Member States, the Commission and, where appropriate, the institution, body, office or agency which adopted the act the validity or interpretation of which is in dispute, shall be entitled to submit statements of case or written observations to the Court." That is why the court analyzes the opinions that were presented by the Land of North Rhine-Westphalia, the Italian Government, Mr. Renckhoff, the French Government and the Commission.

21 "It seems misconceived to say that ... [links]...constitute making available...all they have done is referred other users to where the files may be readily found. In other words, they have provided a form of citation to the copyright works. Thus, it is submitted that inserting a hyperlink in this manner would not and should not constitute making available to the public." Aplin, TAnya. Copyright Law in the Digital Society: The Challenges of Multimedia, London, Hart Publishing, 2005, 320 p. This same criterion was defended in Paperboy case I ZR 259/00 (17 July 2003) in Germany and Perfect 10 vs. Google, Inc., 416 F.Supp.2d 828 (C.D.Cal.2006), 487 F.3d 701 (usca, 9 ${ }^{\text {th }}$ Cir. 2007) in United States. As Abella J. explained in Canadian case Crookes vs. Newton, [2011] 
into a criticism of the Svensson ruling, since it is not the subject of this analysis, I must point out that this criterion of the "new public" is not recognized in Union law. It was an extra requirement created by the CJeu itself ${ }^{22}$.

Paragraph 35 of the judgment is therefore confusing, inaccurate, and incongruous, since here the CJEU is attempting to introduce into the discussion of the case the controversial doctrine of the "new public" brought about by the Svensson judgment. If we were to state that the Cordoba and Svensson cases are the same, taking into account that the first communication was made with a totally open character and without restrictions, no "new public" could be considered to exist and therefore, there would be no act of communication or infraction. Here the weakness of the so-called "new public" criterion is evident, that if we apply it in the same way to Cordoba, we would have to affirm that it is not an act of communication, when it is. In my opinion, the court in the Cordoba case should not have used this theory, but rather missed a perfect opportunity to criticize it. I believe that in the Svensson case, which has had serious implications for subsequent cases, another strategy should have been adopted and this theory of the "new public" should not have been used ${ }^{23}$, which has brought about so many questionable interpretations.

A direct analogy should not be established between Svensson and Cordoba, because they are not similar cases. While in Svensson only one link was established and no work was copied, in the Córdoba case a work that was on a website was reproduced on another server and uploaded. Clearly, there is a difference between both cases. The hyperlink would be a "secondary communication" ${ }^{24}$ which will

SCC 47, [2011] SCR 269, at [26], [30], (in a case concerning hyperlinks and defamation): "Communicating something is very different from merely communicating that something exists or where it exists. The former involves dissemination of the content, and suggests control over both the content and whether the content will reach an audience at all, while the latter does not.... Hyperlinks ... share the same relationship with the content to which they refer as do references. Both communicate that something exists, but do not, by themselves, communicate its content. And they both require some act on the part of a third party before he or she gains access to the content. The fact that access to that content is far easier with hyperlinks than with footnotes does not change the reality that a hyperlink, by itself, is content-neutral - it expresses no opinion, nor does it have any control over, the content to which it refers". These arguments are supported by the European Copyright Society and in my opinion, they are the criteria that should have been followed in the Svensson case and not the controversial theory of the "new public", which has caused so much legal uncertainty.

22 Dr. Mihály J. Ficsor in his document "Svensson: honest attempt at establishing due balance concerning the use of hyperlinks - spoiled by the erroneous 'new public' theory" makes a deep and extensive criticism of the Svensson ruling and particularly the use of the "new public" criterion. Retrieved on 9/7/2020 from [http://www.copyrightseesaw.net/en/papers?page $=5$ ].

23 Hugenholtz P. B. and Van Velze, S. C. "Communication to a new public? three reasons why EU copyright law can do without a "New public'", In IIC-International Review of Intellectual Property and Competition Law. April, 2016. 47(7), p. 797-816. This same criterion has been used by the European Copyright Society in its analysis of the Svensson case. Retrieved on 9/7/2020 from [https://europeancopyrightsociety.org/ opinion-on-the-reference-to-the-cjeu-in-case-c-46612-svensson/].

24 "There is a secondary communication only when there is a retransmission of a communication. In the case of Dirk Renckhoff, it was not the communication made by www.schwarzaufweiss that was retransmitted ... on the contrary, the school communicated 
always depend on a "primary communication", if the original source disappears, the link will be useless. In the case of a hyperlink, the author will always maintain control over the work and can always remove it from the primary site. "On the other hand, uploading the work and making it available on another site is an act of primary communication, which is no longer dependent on any initial communication" 25 . In the Cordoba case, a first act of reproduction is committed and by uploading this copy to the school's website a new act of communication is carried out, totally independent and different from the one made in the travel site. According to the European Copyright Society "in the former situation the copyright holder is no longer in a position to exercise his power of control over the communication of that content."26.

The court continues assessing possible implications of not recognizing these acts as a "communication to the public". To affirm that copying and uploading the photograph is not an act of communication would be to apply indirectly the rule of exhaustion to the right of communication to the public. This conclusion is also established by the court ${ }^{27}$. The exhaustion as a limitation to the author's right applies, by European standards, only to the right of distribution (Article 4.2 Directive 2001/29/EC ${ }^{28}$ ). It should be noted that Article 3.3 expressly prohibits the application of the doctrine of exhaustion to the right of communication to the public. In this respect we must also take into account Recital 28 and $29^{[29]}$ of the Directive 2001/29/EC and the Tom Kabinet judgment (C263/18), where it is concluded that exhaustion affects the physical copies of the work and in this case we are referring to a digital photograph. It is another element against the application of exhaustion to this case ${ }^{30}$.

the photo using a copy residing on its own site". Association Littéraire et Artistique Internationale (ALAI) opinion on case C/161/17. Retrieved on 13/7/2020 from [https:// www.alai.org/en/assets/files/resolutions/180529-opinion-land-nordrhein-westfalen-en.pdf] .

25 Synodinou, T. E. "The Renckhoff case: 6 degrees of separation from the lawful user”, In Era Forum. July, vol. 20, n. ${ }^{\circ}$ 1, 2019, pp. 21-33. Springer Berlin Heidelberg.

26 Retrieved on 9/7/2020 from [https://europeancopyrightsocietydotorg.files.wordpress. com/2018/10/ecs-opinion-renckhoff-cordoba-final.pdf].

27 "Article 3(3) of Directive 2001/29 specifically provides that the right of communication to the public ... is not exhausted by any act of communication to the public or making available to the public within the meaning of that provision... To hold that the posting on one website of a work previously communicated on another website with the consent of the copyright holder does not constitute making available to a new public would amount to applying an exhaustion rule to the right of communication.” [para. 33].

28 “[... 2. The distribution right shall not be exhausted within the Community in respect of the original or copies of the work, except where the first sale or other transfer of ownership in the Community of that object is made by the rightholder or with his consent."

29 Recital 28: "Copyright protection under this Directive includes the exclusive right to control distribution of the work incorporated in a tangible article...". Recital 29: "The question of exhaustion does not arise in the case of services and on-line services in particular... Unlike $\mathrm{CD}-\mathrm{ROM}$ or $\mathrm{CD}-\mathrm{I}$, where the intellectual property is incorporated in a material medium, namely an item of goods, every on-line service is in fact an act which should be subject to authorisation where the copyright or related right so provides".

30 It is obvious that the rules developed in the Oracle case (C-128/11) do not apply here either, since it is a photograph, not software. 


\subsection{Educational context as a possible exception}

The reason for the CJEU interpretation is only with regard to whether the act carried out constitutes a public communication of the work. Nevertheless, I consider that the court should have at least developed some arguments on the possible application to this particular case of an exception based on educational purposes (it referred to this issue to some extent in paragraphs 42 and 43, albeit superficially). This analysis is important in determining whether, or not, the act performed by the student and the school eventually constitutes an infringement, and in this respect I agree with the Advocate General's assertion that considerations of reasonableness should be applicable ${ }^{31}$.

Under the particular conditions of the case, it could be said that the criteria of the three-step test are met, since this exception is expressly defined in German $\mathrm{law}^{32}$. Also, there is no conflict with the normal exploitation of the work and no unreasonable prejudice to the legitimate interests of the right holder. While Recital 4 and 9 of Directive 2001/29/EC foster a high level of protection for authors, we should not forget that copyright is based on a balance between the rights of users to access works and the rights of right holders to obtain fair remuneration. The use of the photograph in this case does not appear to affect the economic interests of the author.

Users' rights are reflected in the exceptions set out in Article 5 of Directive 2001/29/EC, one of which is "use for educational purposes". Although the exceptions and limitations to rights must, in principle, be interpreted restrictively, we should remember that the education is a fundamental right recognized in Article 14 of the Charter of Fundamental Rights and must not be unjustifiably limited either. Correct proportionality must therefore be established in these cases, seeking to preserve the balance that must characterize copyright ${ }^{33}$. In this particular case, although it is an infringement of the right of communication to the public as we discussed before, I believe that exceptions such as those in Article 5(3)(a) and 5(3)(d) of the Directive 2001/29/EC (transposed into German law by the Urheberrechtsgesetz - UrhG) can be applied to the main proceeding.

31 This exception can be found in Article 10 of the Berne Convention, and was adopted by Directive 2001/29/EC in its article 5(3)(a) and (d).

32 The Urheberrechtsgesetz - UrhG (Act on Copyright and Related Rights) recognizes in its subdivision 4 Lawfully permitted uses for teaching, science and institutions. Specifically, in section 60a (2), the copyright exception for educational and teaching purposes is legally recognized.

33 As recognized in Recital 31 of the Infosoc Directive: "a fair balance of rights and interests between [...] the different categories of rightholders and users of protected subject-matter must be safeguarded". 


\section{BIBLIOGRAPHY}

Association Littéraire et artistique internationale. Opinion on case C/161/17. Retrieved on 13/7/2020 from [https://www.alai.org/en/assets/files/ resolutions/180529-opinion-land-nordrhein-westfalen-en.pdf].

Aplin, Tanya. Copyright Law in the Digital Society: The Challenges of Multimedia, London, Hart Publishing, 2005.

FiCsOR, MinÁly. "Svensson: honest attempt at establishing due balance concerning the use of hyperlinks, spoiled by the erroneous 'new public' theory", Retrieved on 9/7/2020 from [http://www.copyrightseesaw.net/en/papers?page=5].

Hugenholtz P. B. and Van Velze, S. C. "Communication to a new public? three reasons why EU copyright law can do without a "New public", In IICInternational Review of Intellectual Property and Competition Law, April, 2016, 47(7), p. 797-816.

Synodinou, T. E. "The Renckhoff case: 6 degrees of separation from the lawful user", In Era Forum, vol. 20, n. ${ }^{\circ}$ 1, July 2019, pp. 21-33. Springer Berlin Heidelberg. 